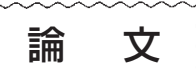

\title{
野生メダカに見出された囊胞に関する病理組織学的所見
}

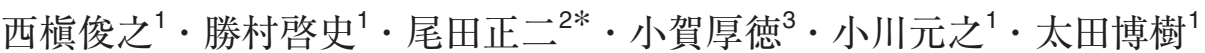

（2015年 6 月19日受付）

\section{Histopathological Features of Cysts in Wild Medaka Fish}

\author{
Toshiyuki Nishimaki ${ }^{1}$, Takafumi Katsumura ${ }^{1}$, Shoji Oda ${ }^{2 *}$, Atsunori Oga ${ }^{3}$, \\ Motoyuki Ogawa ${ }^{1}$ and Hiroki Oota ${ }^{1}$ \\ ${ }^{1}$ Department of Anatomy, Kitasato University School of Medicine, Kanagawa 252-0374, Japan \\ ${ }^{2}$ Department of Integrated Biosciences, Graduate School of Frontier Sciences, \\ The University of Tokyo, Chiba 277-8562, Japan \\ ${ }^{3}$ Department of Pathology, Yamaguchi University Graduate School of Medicine, \\ Yamaguchi 755-8505, Japan
}

(Received June 19, 2015)

\begin{abstract}
Pathogenic studies using model animals for diseases that are found in similar diagnosis as in humans are widespreading and medaka fish Oryzias latipes is one of such animal models, however, histological studies on their diseases are still limited. In this study, we applied whole body serial tissue sectioning to adult medaka; it is similar to whole body computed tomography (CT) scanning to decide the lesion (s) location, furthermore, it can give us more precisely microscopic histological information. When adult medaka collected from a wild population were examined, we found cystic lesion (s) in their testis with a diameter of about $500 \mu \mathrm{m}$, filled with serous material. Because each of cysts was covered with epithelium, the lesion was found to be a true cyst. Cysts with the same histological appearance were also found adjacent to ovary and liver, and some of the medaka showed polycystic condition. This condition was seen at a high frequency in wild medaka, but it had not been found in laboratory-reared medaka. Although number of observations is small for giving conclusion, these results suggest that cysts could be a common lesion in wild medaka and whole body sectioning can be a powerful methodology for pathological examination of model animal like medaka.
\end{abstract}

Key words: Cyst, medaka, whole body serial tissue section, polycystic kidney disease

Cyst（囊胞）は病理学的に上皮で内面をおおわれた袋 状のものを指し，経過によって内面の上皮が不明になる こともあり，腫瘍性の場合もある。通常，その内腔は液 体または半固体状の物質で満たされ，単房性または多房 性で閉ざされる。精巣における囊胞は，古くはヒトでは 稀な疾患とされていたが超音波診断等の診断法の発達と 普及にともなって初期病変の診断が容易となり，現在で

\footnotetext{
1 北里大学医学部解剖学

2 東京大学大学院新領域創成科学研究科先端生命科学専攻

3 山口大学大学院医学系研究科分子病理 - 第二病理学

* Corresponding author

E-mail: odasho@k.u-tokyo.ac.jp
}

は比較的高い頻度で観察される疾患である（Gooding et al., 1987 ; 増田ら, 1993)。ヒ卜以外の生物においても襄 胞が生じていると考えられ，その形成原因等を究明する ことはヒトの囊胞の発生メカニズムを明らかにする手が かりを与えるものと期待できるが，一部のモデル生物を 除いて異胞に関する知見はほとんど無いのが現状である。 本稿では，生物学拉よび医学の分野でモデル生物とし て多用されるメダカ Oryzias latipes に扔いて, 囊胞の有 無を探索した。メダカの体躯が小さい（体長約 $3 \mathrm{~cm}$ ）こ とを活かしてメダカの全身より矢状面によるパラフィン 連続組織切片を作製し，メダカの全身組織において病理 組織学的な検討を行い，精巣抒よび卵巣に単房性および 
多房性の囊胞様組織異常を見出したので，ここに報告す る。

\section{材料および方法}

\section{供試魚}

石川県で採取した野生メダカ（体長 $2.5 \mathrm{~cm}$ 前後）の成 魚を雌雄各 4 匹ずつ使用した。メダカは北里大学医学部 動物実験取扱規定に従って, 苦痛を与えずに安楽死させ た。

\section{連続全身組織切片の作製および病理組織学的観察}

外観における異常の有無を観察した上で，安楽死させ たメダカを Davidson 氏固定液に浸し，室温で10日間固 定した。固定後，定法にならってパラフィン包埋し，滑 走式ミクロトーム（リトラトーム REM700，大和光機工 業株式会社）を使用して厚さ $5 \mu \mathrm{m}$ の矢状面および横断 面によるパラフィン連続全身組織切片を作製した（尾田 ら，2014）。作製した全身組織切片を脱パラフィン・脱ア ルコール・水洗した後に, ヘマトキシリン・エオジン （HE）染色もしくはアルシアンブルーPAS 染色を施し, 光学顕微鏡下にて鏡検した。

\section{結果}

\section{精巣囊胞}

外見上，野生雄メダカには特に異常等は認められな かった。雄のメダカ成魚のパラフィン全身組織切片に押
いて探索した結果, 本研究において検討を行った野生メ ダカ雄成魚 4 匹のうち 3 匹において通常の精巣では認め られない $1 \sim 4$ 個の囊胞様の組織異常を精巣近傍に認め た (Fig. 1A ; 矢状面切片)。メダカの精巣では周辺部に精 原細胞を含む精巣小葉が位置し, 一つの精巣小葉に内含 される精原細胞がクローナルに増殖し精子形成を進める につれて，精巣深部に位置するようになる（Fig. 1B；横 断面切片)。完成した精子は細精管に続く輸精小管内を精 巣深部へ移送され，精巣後半部の背部中央に位置する輸 出管に集合・貯留される（濱口，1990）。囊胞様構造は 直径が約 $500 \mu \mathrm{m}$ であり, その内部は HE 染色において 染色されない均質な成分で満たされていたことから，哺 乳類における囊胞と同様の組織構造異常であるものと考 えられたが, 囊胞によっては内部中心付近に細胞塊らし き構造を有する場合も認められた（Fig. 1C）。矢状面切 片において観察された囊胞様構造はほとんどの場合精巣 後半部位の背側に位置したが, 正常な精巣組織構造の内 部に囊胞が形成される像も観察された（Fig. 1D）。精巣 近傍に生じた囊胞が精巣内部の構造に由来することは,

Fig. 2 に示される組織像によっても明暸に確認された。 すなわち, 囊胞は重層扁平上皮様の薄い角質化した細胞 層によって覆われるが，その細胞層を覆う結合組織様細 胞層は精巣内部の細精管・輸精小管の壁を構成する細胞 層と連続していた（Fig. 2B）。さらに Fig. 2A に示される 囊胞では内部の細胞塊が精子に由来するものと考えられ ることから (Fig. 2C), 今回の野生メダカ精巣に見出さ

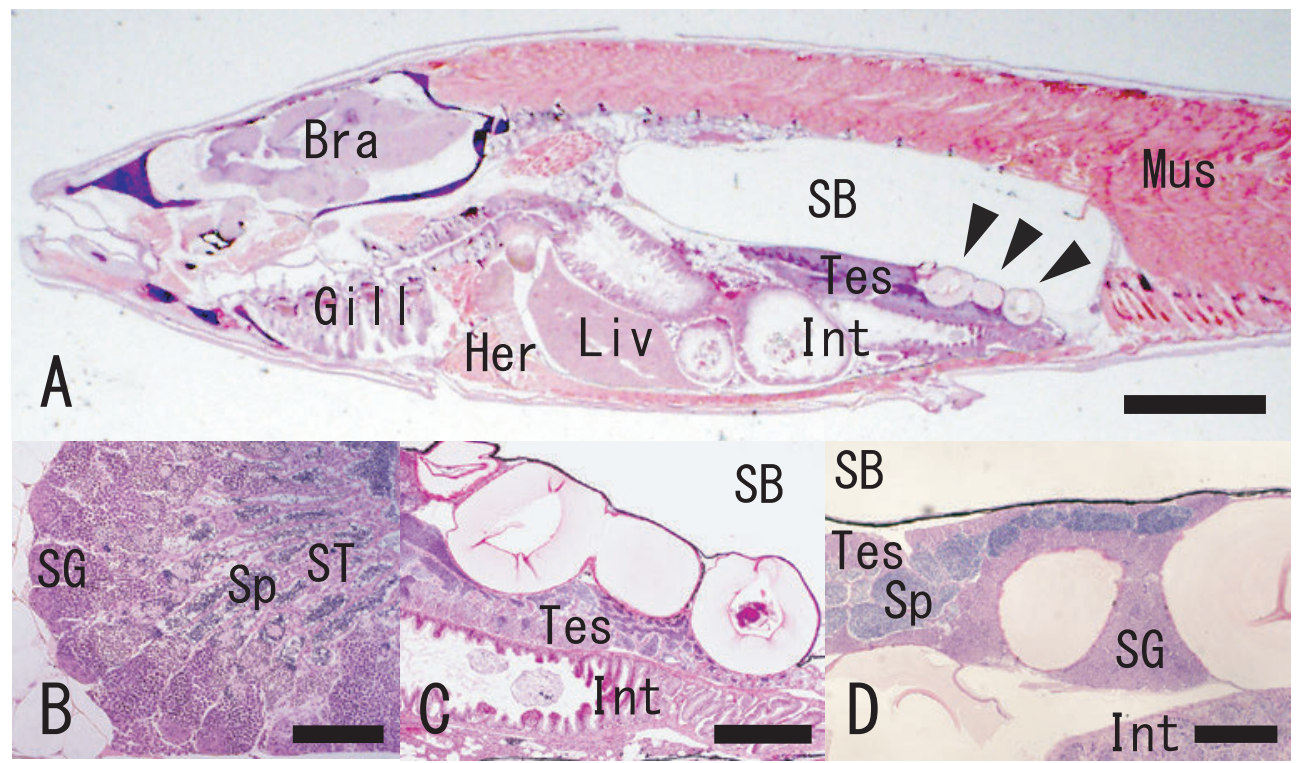

Fig. 1. Paraffin-embedded whole tissue section of a wild adult male (A). Arrowheads in A indicate the cysts in the testis. In the normal testis (B), spermatogonia (SG) locate peripherally and matured sperm (small grains stained deeply in B, C, D are nuclei of matured sperm; Sp) are transfered through seminiferous tubule (ST) in the deeper part of testis. C show the magnified images of sections of the testis with cysts shown in $A$. In sections from another male, cysts located inside of the testis (D) surrounded by proliferating spermatogonia. Bars represent $2 \mathrm{~mm}, 100 \mu \mathrm{m}, 200 \mu \mathrm{m}$, and $200 \mu \mathrm{m}$ in $\mathrm{A}, \mathrm{B}, \mathrm{C}$ and $\mathrm{D}$, respectively. SB: swim bladder, Liv: liver, Tes: testis, Int: intestine, Her: heart, Mus: muscle, Bra: brain. 


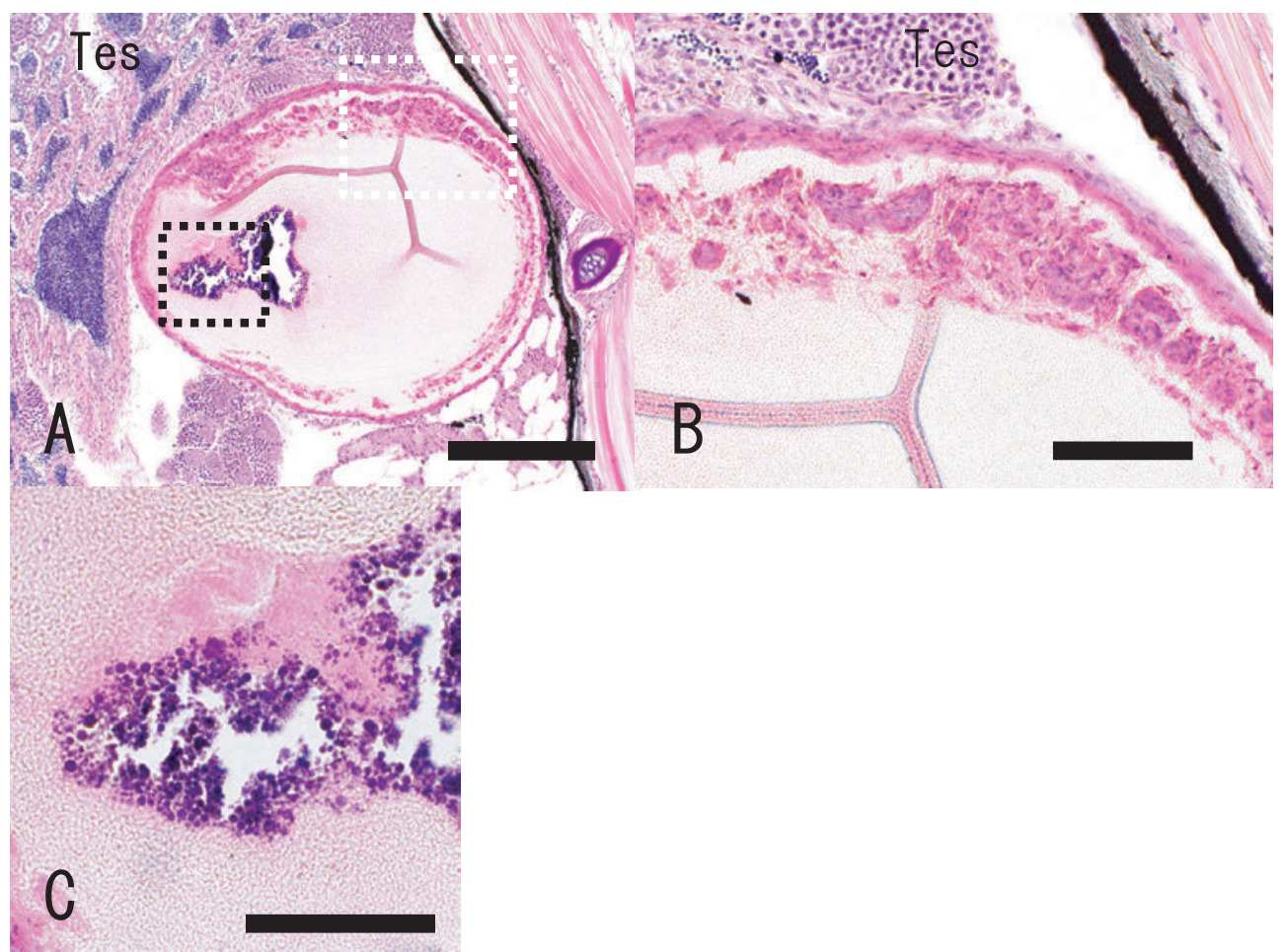

Fig. 2. Some of the cysts in the testis contained cell mass in its central part and/or the peripheral part. B shows a higher magnified image of the white boxed region in A, representing that the squamous epithelium of the cyst originated from the tissue of the testis. C shows a higher magnified image of the black boxed region in $A$, with mass of cells with very small nucleus, presumably degenerating spermatozoa. Bars represent $200 \mu \mathrm{m}, 50 \mu \mathrm{m}$ and $50 \mu \mathrm{m}$ in A, B, and C, respectively. Tes: testis.

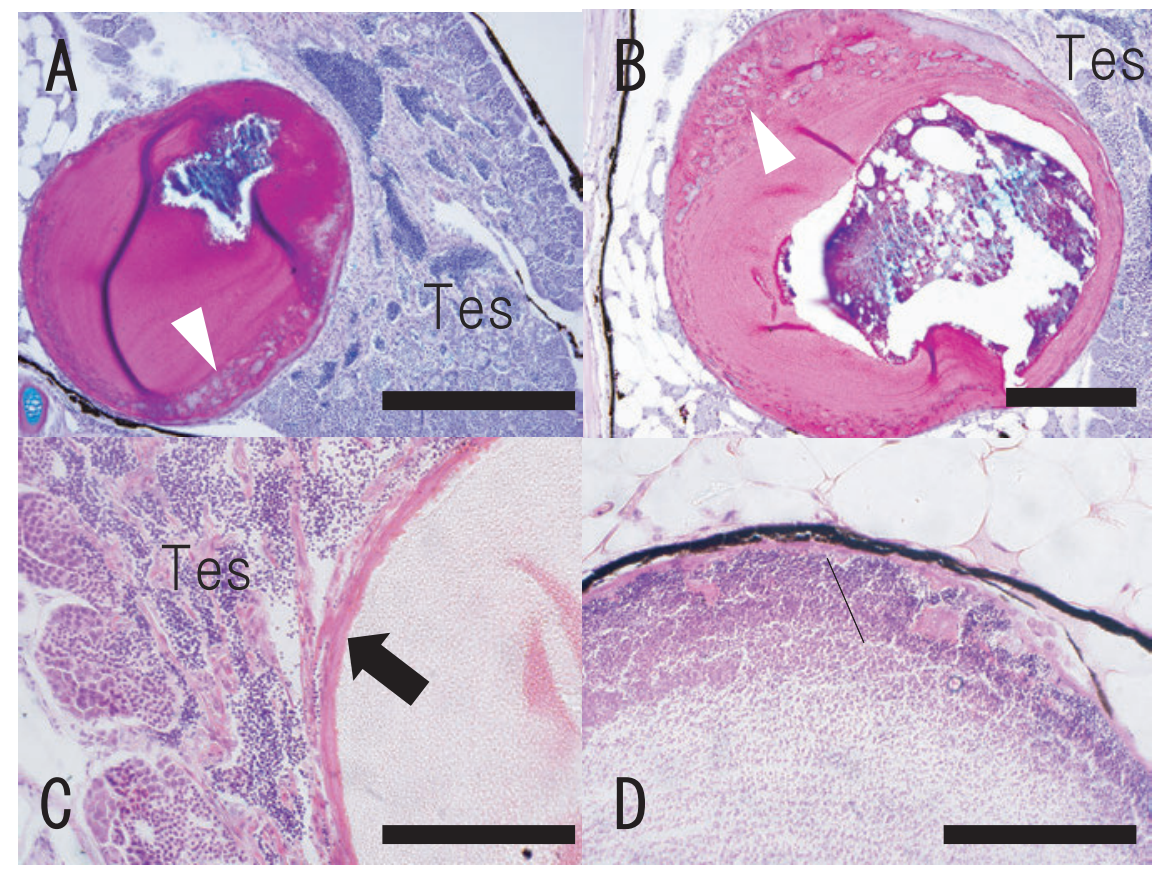

Fig. 3. Cross sections of the testicular cysts in wild adult males are presented. The contents of the testicular cyst were stained in violet deeply by Alcian Blue - PAS staining (A, B) in the same way as the cysts in ovary (Fig. 7). In the cysts shown in A and $B$, rete-like structures (white arrowheads) are present in the peripheral regions, which are likely degenerating seminal ducts in the testis, strongly suggesting that the testicular cysts are originated not in gametes, but the testicular structure. Squamous epithelium (arrow) of the cyst shown in $\mathrm{C}$ is continuous with the tubular wall of the seminal ducts in testis. Some testicular cysts contained numerous spermatozoa inside $(D)$. These findings stronlgy support the idea that the testicular cysts are originated in the testicular structure, presumably seminal ducts in testis. Bars represent $200 \mu \mathrm{m}$ in A, B and $100 \mu \mathrm{m}$ in C, D. 


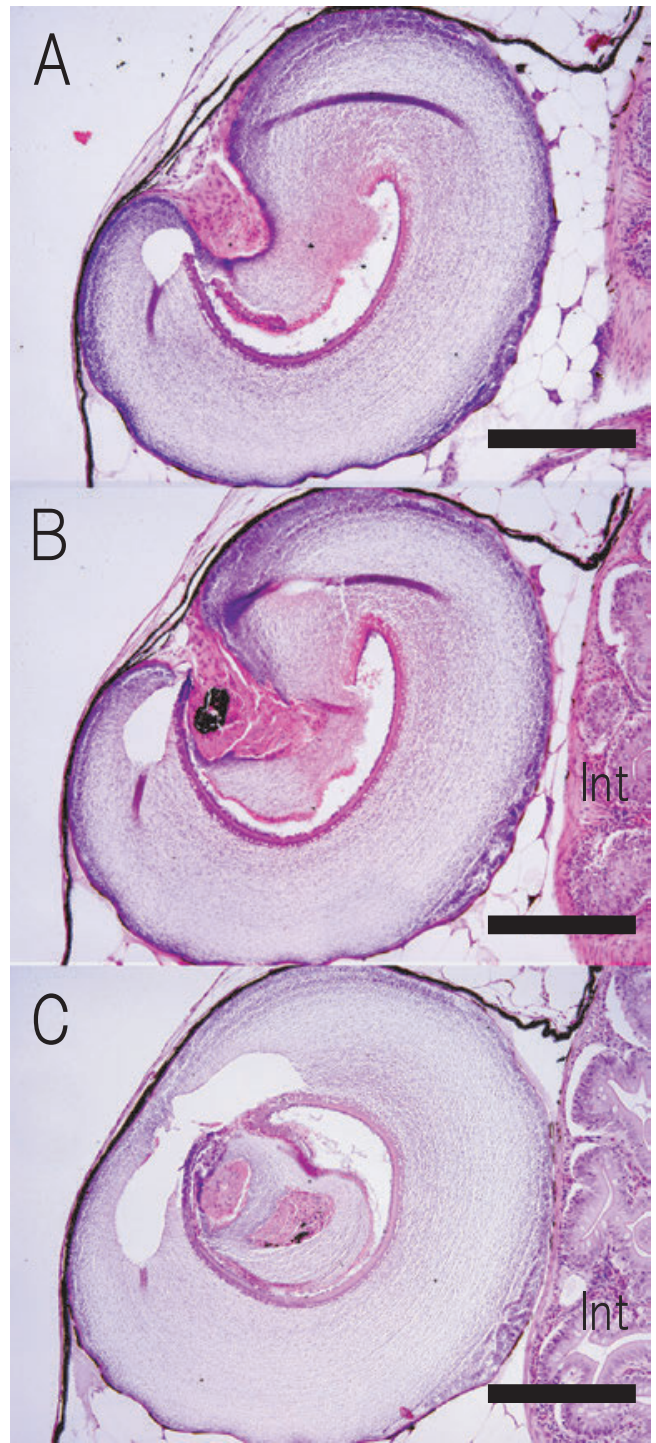

Fig. 4. Three serial sections of a cyst in a wild adult male are presented $(A-C)$. Arrowheads in $A$ and $B$ represent that cells outside of the testis were included into the cyst, which can be the origin of the cell mass in the central part of some cysts (C). Bars represent 200 $\mu \mathrm{m}$. Int: intestine.

れた囊胞は，精巣内部の輸精小管の一部が肥大・膨潤化 したものと考えられる。

組織切片をアルシアンブルーPAS 染色したところ，囊 胞の内容物が紫色に濃染されたことから，囊胞が漿液性 の内容物で満たされていることが強く示唆された（Fig. 3A，B）。Fig. 3A，Bに示す精巣囊胞では，囊胞を覆う上 皮様組織の一部が網目状の構造をみせること, 囊胞を覆 う上皮様組織が細精管もしくは輸精小管の隔壁を成す細 胞組織と連続していること (Fig. 3C)，そして内腔に大 量の精子を貯留する襄胞が存在したこと（Fig. 3D）か ら，これら精巣囊胞が細精管もしくは輸精小管に由来す る可能性が強く支持された。一方, Fig. 4 に連続切片像

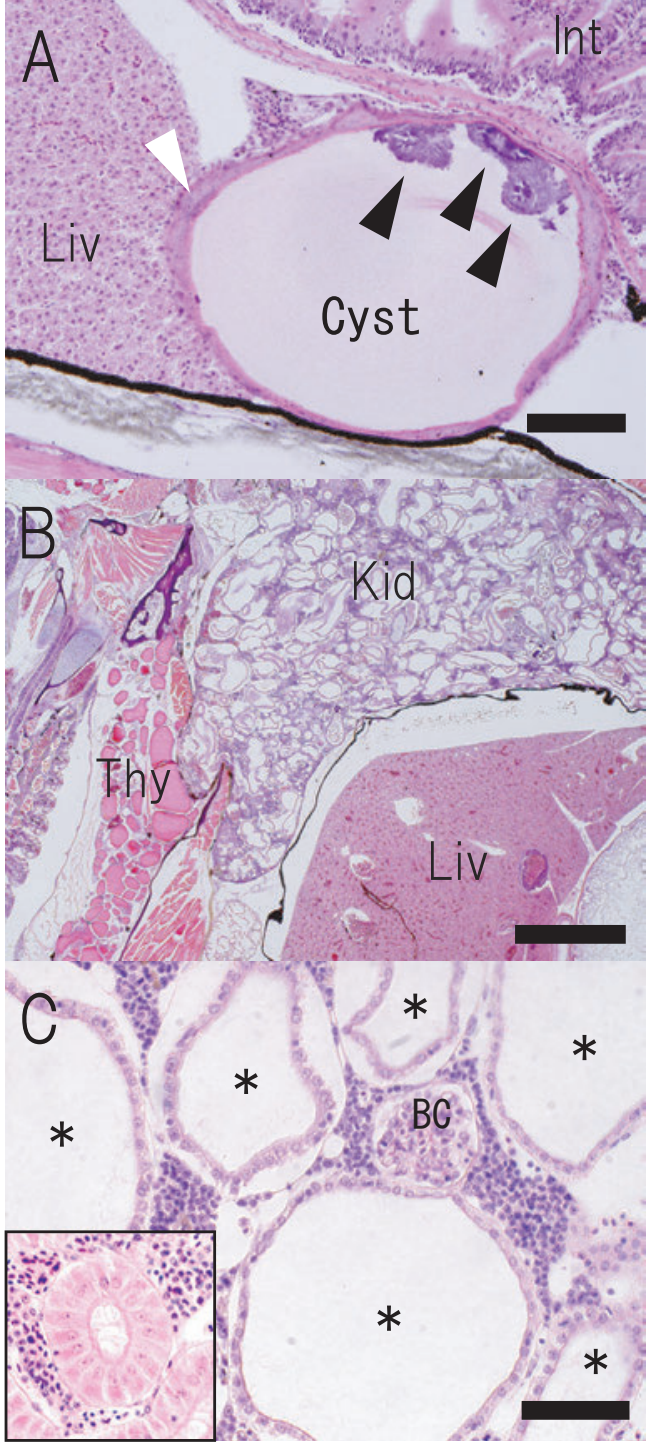

Fig. 5. In some of the fish examined, cysts developed adjacent to liver, of which structure was almost the same as the cysts in the testis (A), covered with squamous epithelium-like structure (white arrowhead) that is closely resemble to that observed in testicular and ovarian cysts (Fig. 2, 3, 6, 7). The cyst shown in A contained irregular structures stained in deep violet by $\mathrm{HE}$ (black arrowheads), of which origin is unknown. It was clear that the cyst shown in $A$ is not gall blader, because the gall blader was present in the more dorsal part of the abdomen of this fish. Tubules in the kidney of some of the fish swelled extensively, showing the histological appearance characteristic to the model fish of polycystic kidney disease $(B, C)$. The parenthesized image in $C$ represents the normal tubule of a healthy fish in the same scale. Asterisks in $C$ indicate the swollen tubules, while a Bowman's capsule (BC) appears intact. Bars represent $200 \mu \mathrm{m}, 500 \mu \mathrm{m}$ and $50 \mu \mathrm{m}$ in $\mathrm{A}, \mathrm{B}$ and $\mathrm{C}$, respectively. Liv: liver, Kid: kidney, Int: intestine, Thy: thyroid.

を示す囊胞では, 囊胞の外部に位置する細胞組織が囊胞 の内腔に陥入して囊胞内腔の細胞塊と連絡しており, 
Fig. 2, 3 に示した囊胞とはその起源と形成過程を異にす るものと考えられる。

さらにこれらの個体では, 肝臟や腎臓などの他の臟器 にも囊胞が認められた。腹腔内の肝臟尾部側に, 精巣に 認められたものとほぼ同じ構造の囊胞が認められた例を Fig. 5A に示す。また，別の精巣囊胞を有した個体では著 しく膨潤化した尿細管によって腎臓が大きく肥大化して 打り（Fig. 5B，C），ヒトに打ける襄胞腎症との症状の類 似性が認められた。

\section{卵巣囊胞}

野生雌メダカの外見上にも特に異常等は認められな かったが，麻酔した雌成魚から摘出した卵巣の表面に2 個の囊胞様組織構造を認めた（Fig. 6A）。肉眼による観察 では, 卵巣内部より突出しているのではなく卵巣の表面 の一部が囊胞化しており，その内腔は液体あるいは半固 体状の内容物で満たされている様に観察された。摘出し た卵巣の組織切片を HE 染色して検鏡したところ，囊胞 はエオジンにより赤色に濃染される重層扁平上皮と考え られる薄い角質化した細胞層でおおわれており, 内腔中 心部に細胞塊が認められた。当該の囊胞と卵巣の内部組
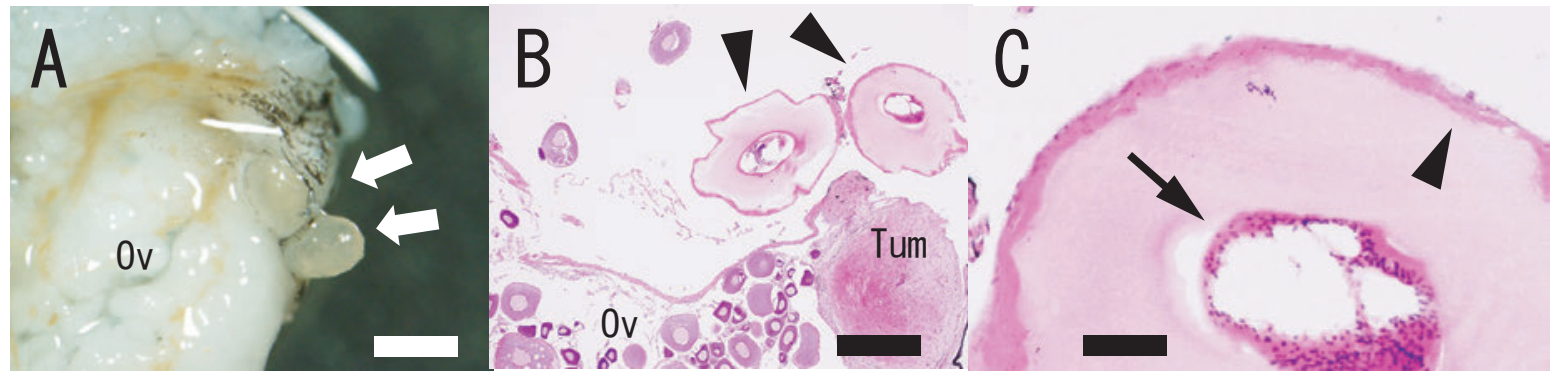

Fig. 6. (A) Two cyst-like structures located on the isolated ovary from a wild female adult medaka (white arrows). The ovary was chemically fixed, sectioned, and HE stained. Cyst (black arrow heads in B) were clearly distinctive from oocytes, since they were much larger than maturing oocytes and surrounded with thin squamous epithelium (arrow head in C). Both cysts contained cell mass in its central part (arrow in C). In B, a large cell mass labeled "Tum" was an abnormal strucure of the ovary, presumably tumor. Bars represent $1 \mathrm{~mm}, 300 \mu \mathrm{m}$, and $50 \mu \mathrm{m}$ in $\mathrm{A}, \mathrm{B}$, and $\mathrm{C}$, respectively. Ov: ovary.

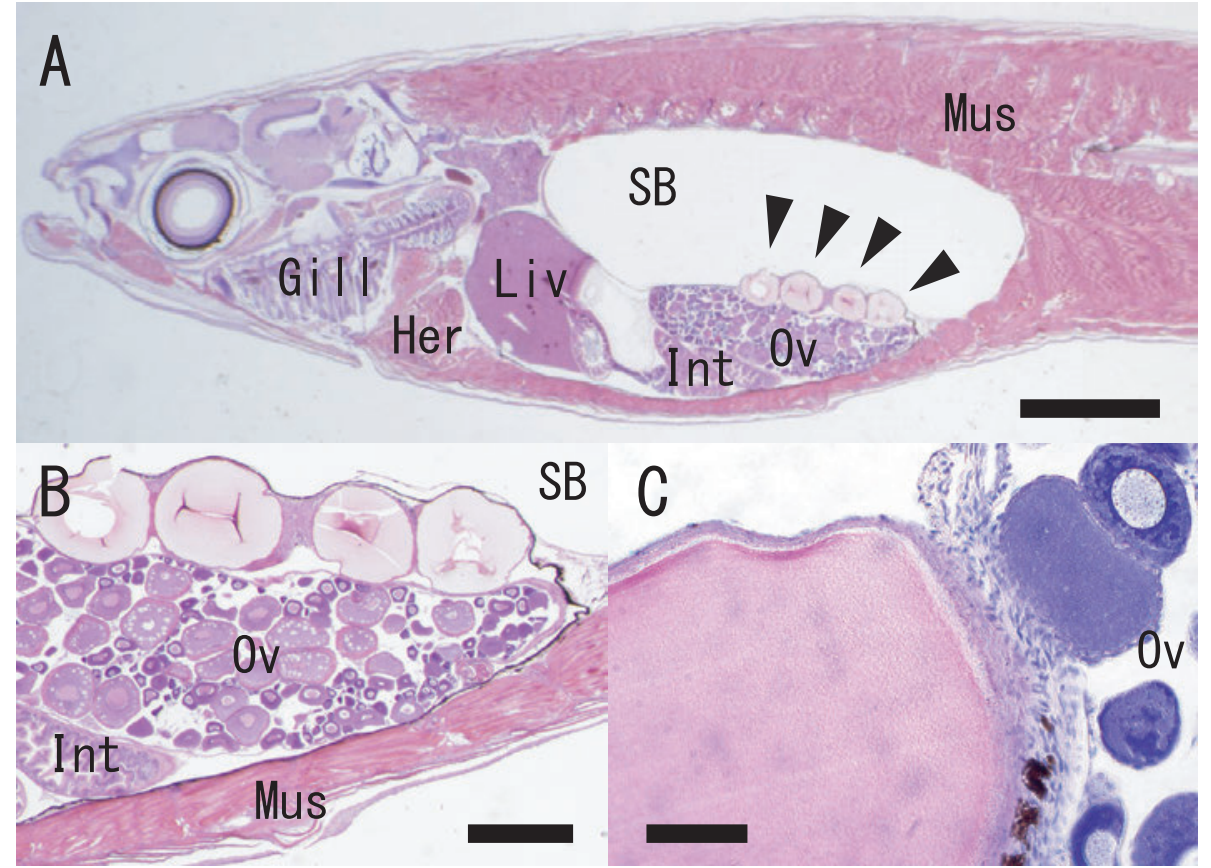

Fig. 7. Paraffin-embedded whole tissue section of wild female (A) and 4 cysts associated with the ovary (arrowheads). B shows the magnified image of the ovary with the cysts in A. C represents a maginified image of a cyst adjacent to the ovary. The contents of the cyst was stained in deep violet with Alcian Blue -PAS Staining, suggesting that the cyst was filled with serous material. The connective tissues surrounding the cyst and ovary fused, suggesting that the origin of the cysts can be tissues associated with ovary, but not oocytes nor other somatic cells in ovary. Bars represent $2 \mathrm{~mm}, 500 \mu \mathrm{m}$, and $50 \mu \mathrm{m}$ in A, B, and C, respectively. SB: swim bladder, Liv: liver, Ov: ovary, Her: heart, Mus: muscle, Int: intestine. 
織との連絡は認められず, 組織学的形態から囊胞は卵細 胞に由来するものでもないと判断した（Fig. 6B，C）。

また, 野生メダカ雌成魚における囊胞様組織構造の分 布とそれらの詳細な構造および周辺の組織構造を観察す るために，パラフィン連続全身組織切片を作製して鏡検 したところ, 腹腔内において卵巣に密接して複数の襄胞 が密集する多囊胞性の組織異常が見出された。卵巣の部 分は正常な組織像を呈していた（Fig. 7A, B)。別の雌メ ダカ成体の腹部クロス切片ではアルシアンブルー染色に より濃染される内容物を有する2個の囊胞が見出された が, その片方の裹胞を覆う結合組織様構造が卵巣を覆う 卵巣壁組織と連続していた（Fig. 7C）。メダカの卵巣は, 様々な発育段階の多数の卵母細胞が卵巣壁に包みこまれ る構造として腹腔内に認識される（Iwamatsu, 1988 ; 濱 口，1990；岩松，1997）。当該の囊胞は卵母細胞あるい は卵巣内部の組織構造とは明らかに独立しており, 卵巣 に接しているものの卵巣の内部構造には由来しないもの と考えられた。野生メダカ雌成魚において見出された卵 巣近傍における囊胞の形状と構造は雄成魚において見出 された精巣囊胞とほぼ同一であり, 輁胞の大きさはいず れも直径が 0.5 $1 \mathrm{~mm}$ であって球体状を呈していた。 また,これら見出されたすべての囊胞を内装する上皮に 腫瘍性異型は認めなかった。

\section{考察}

本研究では, メダカ成魚の全身組織連続切片を作製し て全組織において病理組織学的に襄胞の有無を検証した 結果, 精巣, 卵巣および肝臓等に単房性および多房性の 囊胞を見出した。これらの囊胞は形状や大きさ, 内部構 造が単純でほぼ同一であったことから, ヒト等哺乳類に おいて囊胞と呼ばれる組織異常に相当するものと判断し た。寄生虫や奇形腫（テラトーマ）の可能性を考虑し, 全身組織連続切片であることを活かして囊胞様組織異常 の構造全体を検討した結果, 細胞器官を思わせるような 組織だった細胞構造や腫瘍性の異型は全く認められな かった。ヒトや他の哺乳類においての病理学的定義では, 囊胞は上皮で内面をおおわれた袋状のものを指し, 経過 によって内面の上皮が不明になることもあるとされる。 ヒトでは, 囊胞を多発する遺伝性疾患が知られており, 常染色体優性遺伝性多発性囊胞腎症では多発腎囊胞のほ か, 頭蓋内 (脳硬膜), 肝臓, 膵臓, 睪丸, 卵巣などにも 囊胞を生じることが知られている。さらにヒトの精巣で は, 水腫や炎症で急速に囊胞が増大する場合, 不妊治療 に関わる場合，あるいは腫瘍化する場合に臨床的に取り 扱われることが多いが, 精巣の検査は一般的ではないこ とから自覚症状が無いものや小さいものは実際上無視さ れ，古くは精巣囊胞の頻度は稀とされていた。Gooding et al.（1987）は307人の男性を対象として無作為に陰囊
超音波検査を実施し，30人（9.8\%）の精巣に囊胞が見出 されたことを報告し, 超音波診断などの手法の発達によ り診断例数は増加の傾向にある。今回メダカ成体におい て見出された震胞は精巣の内部組織に由来する構造異常 と考えられる。特に Fig. 2 および Fig. 3 に示される例で は囊胞内腔に多数の精子細胞が存在し，あるいは内腔が 多量の精子で満たされ震胞の上皮様組織が細精管もしく は輸精小管の隔壁組織に連続していたことから，精巣囊 胞が輸精小管の一部の局所的な膨大化に由来する可能性 が考えられ，本報告におけるメダカの精巣囊胞はヒトに おける精巣上体囊胞と相同のものである可能性がある。 精巣豪胞の大半が精巣の尾部側・背側の, 輸精小管が合 流した輸出管部と同じ位置に頻繁に見出されたことも,

精巣囊胞の原因を輸精小管の膨大化と考えることに矛盾 しない。しかし, Fig. 4 にその連続切片を示した囊胞で は囊胞外部に位置する細胞塊が囊胞内腔に陥入して囊胞 の内腔中心部の細胞塊と連絡しており, 輸精管の膨大化 に由来するとは考えられず, メダカ精巣囊胞の由来が単 一ではない可能性を示している。

精巣囊胞を有していた雄成魚において，尿細管が膨潤 化し重篤な囊胞腎の症状を呈している個体が認められ (Fig. 5B，C), 常染色体優性遺伝性多発性囊胞腎症のモ デルとして報告されている $p c$ 変異体メダカにおける腎蔵 の組織像と極めて類似していた Mochizuki et al., 2005）。ヒト多発性囊胞腎症においては, 肝囊胞の形成 に加えて精巣囊胞が形成される症例も知られているが, $p c$ 変異体メダカでは精巣震胞の形成は報告されていない ことから, 本研究で報告するメダカの多発性囊胞腎症様 症例とは発症メカニズムが異なる可能性も考えられる。

一方, メダカの䧳成体においても雄で見出された精巣 囊胞に極めて類似した構造の囊胞が卵巣近傍に見出され た。ヒトにおける卵巣囊胞の場合には，妊娠や体調不良 などでの検査によって卵巣囊胞が発見される機会が多く, 男性の場合より臨床的に検討される機会は多い。腫瘍以 外に, 機能性の黄体囊胞や卵胞囊胞のほか, 単純性囊胞 とされるもの, 子宮内膜症によるもの, 卵巣や卵管の周 辺に囊胞を生じる傍卵管 (卵巣) 囊胞が病理検査でしば しば経験される。今回メダカにおいて卵巣近傍に見出さ れた囊胞の構造は単純であり, 魚類と哺乳類の生殖様式 の違いから黄体囊胞, 卵胞囊胞, 子宮内膜症関連の組織 異常と相同であるものと考えることには難があり, ヒト の知見と単純に比較検討することはできない。メダカ卵 巣近傍に見出された精巣囊胞とほぼ同じ構造を有する囊 胞の組織学的な由来に関しては不明であり, 今後の課題 である。哺乳類においては精巣上体・輸精管はウォルフ 管をその起源とし，雌個体においては卵管等の組織構造 がミュラー管に由来するのに対して，魚類においては雄 において輸出管から輸精管にかかる部位はウォルフ管に 
は由来せず，また雌に扔いてもミュラー管を欠くなど， 哺乳類と魚類においては生殖腺に付属する管構造の起源 が全く異なることが知られている (Suzuki and Shibata, 2004)。今回, ほほ同じ構造の囊胞がメダカの精巣・卵 巣に見出されたことは, 魚類特有の発生様式に起因する 可能性も考えられる。

今回調查した野生メダカに拈いては 8 匹中 6 匹 （75.0\%）に押いて卵巣㧍よび精巣に単房性扮よび多房性 の囊胞が発生していたことから, 野生のメダカでは稀な 病変ではない可能性も考えられる。しかし, メダカ (Oryzias latipes) は日本各地域で遺伝的に高度に種内分 化しているため (Takehana et al., 2003; Kasahara et al., 2007; Katsumura ら 2009), 他の野生メダカ集団が 本論文で報告する石川県産のメダカと同様の発症頻度を 示すかどうかは不明である。四国の一部地域で採取した 野生メダカでは，6 匹中に 6 匹（100\%）の割合で卵巣お よび精巣で囊胞の発生が認められた（西橹ら，未公表)。 その一方で, 本研究室の実験室内で管理・飼育されたメ ダカをこれまでに約100個体について調べたが，囊胞の発 生は今までに全く経験していない（西租ら，未発表）。実 験室環境に比べ野生環境下のメダカにおいて囊胞発生の 頻度が高いという知見は, 囊胞の発生が実験室飼育環境 になくて野生環境にある何らかの環境要因に起因する可 能性を示唆するものとも考えられる。野生入ダカにおい て精巣および卵巣囊胞がより頻発に見出された原因とそ の機序については今後の検討が必要である。

メダカに限らず魚類全般にわたり精巣および卵巣囊胞 に関する報告例は極めて少ない。本研究によるメダカの 精巣㧍よび卵巣囊胞の形状や内部構造に関する病理組織 学的な記載は, 疾患モデル生物として用いられているメ ダカのみならず，他魚種に抢ける襄胞の病理学的解明の 基礎となるものと期待される。本研究において, 疾患を 病理学組織的に検討する場合に, 全臟器の病変を網羅的 に検討できる連続全身組織切片法はメダカのような小型 のモデル魚類において全身組織を網羅的に探索する目的 に特に有用であることが改めて示された。今後，メダカ やゼブラフィッシュ等の小型のモデル魚類を対象とした 連続全身組織切片法を用いることによって，他の病変に ついても病理組織学的研究が進むものと期待される。

\section{文献}

Gooding, G. A., W. Leonhardt and R. Stein (1987): Testicular cysts: US findings. Radiology, 163, 537-538.

濱口 哲（1990）：生殖細胞の分化,「メダカの生物学, 江上信 雄, 山上健次郎, 嶋 昭紘編」, 東京大学出版会, 東京, pp. 7-27.

Iwamatsu, T., T. Ohta, E. Oshima and N. Sakai (1988): Oogenesis in the Medaka Oryzias latipes - Stages of Oocyte Development: Developmental Biology. Zoological sci., 5, 353-373.

岩松鷹司 (1997) : メダカ学全書, 大学教育出版, 岡山, pp. 167-168.

Kasahara, M., K. Naruse, S. Sasaki, Y. Nakatani, W. Qu, B. Ahsan, T. Yamada, Y. Nagayasu, K. Doi, Y. Kasai, T. Jindo, D. Kobayashi, A. Shimada, A. Toyoda, Y. Kuroki, A. Fujiyama, T. Sasaki, A. Shimizu, S. Asakawa, N. Shimizu, S. Hashimoto, J. Yang, Y. Lee, K. Matsushima, S. Sugano, M. Sakaizumi, T. Narita, K. Ohishi, S. Haga, F. Ohta, H. Nomoto, K. Nogata, T. Morishita, T. Endo, I. T. Shin, H. Takeda, S. Morishita and Y. Kohara (2007): The medaka draft genome and insights into vertebrate genome evolution. Nature, 447, 714-719.

Katsumura, T., S. Oda, S. Mano, N. Suguro, K. Watanabe, H. Mitani, H. Oota and S. Kawamura (2009): Genetic differentiation among local populations of medaka fish (Oryzias latipes) evaluated through grid-and deme-based sampling. Gene, 443, 170-177.

増田 均 - 山田拓已 - 長浜克志 - 永松秀樹 - 根岸壮治 - 森本信 二 (1993)：囊胞性精巣病変の3 例：単純性精巣囊胞, 精 巣白膜囊胞, 囊胞性成熟奇形腫の各 1 例。泌尿器科紀要, 39, 265-268.

Mochizuki, E., K. Fukuta, T. Tada, T. Harada, N. Watanabe, S. Matsuo, H. Hashimoto, K. Ozato and Y. Wakamatsu (2005): Fish mesonephric model of polycystic kidney disease in medaka (Oryzias latipes) pc mutant. Kidney Int., 68, 23-34.

尾田正二 · 西䬱俊之 · 勝村啓史 ·片田吉彦 - 小賀厚徳 - 池本健 三・谷口善仁 ·太田博樹 (2014) : 連続全身組織切片と24 時間トラッキングによるメダカの組織形態と活動性の網羅 的な解析. Cytometory Research, 24, 9-14.

Suzuki, A. and N. Shibata (2004): Developmental process of genital ducts in the medaka, Oryzias latipes. Zoological sci., 21, 397-406.

Takehana, Y., N. Nagai, M. Matsuda, K. Tsuchiya and M. Sakaizumi (2003): Geographic variation and diversity of the cytochrome $b$ gene in Japanese wild populations of medaka, Oryzias latipes. Zoological sci., 20, 12791291. 